\title{
Peran Ombudsman Republik Indonesia (ORI) Perwakilan Sulawesi Selatan Dalam Pengawasan Pelayanan Publik Di Kota Makassar
}

Oleh :

Hamrun

Ahmad Taufik

Hamrun07@gmail.com

taufikunismuh@gmail.com

\section{IImu Pemerintahan Fakultas IImu Sosial Dan IImu Politik Universitas Muhammadiyah Makassar}

\begin{abstract}
Abstrak
Tujuan dari penelitian ini yaitu untuk mengetahui Peran Ombudsman Republik Indonesia (ORI) Perwakilan Sulawesi Selatan dalam Pengawasan Pelayanan Publik Di Kota Makassar dan Untuk mengetahui Faktor-faktor yang Mempengaruhi Kinerja Ombudsman (ORI) Perwakilan Sulawesi Selatan Dalam Mengawasi Kebijakan Publik Di Kota Makassar. Jenis penelitian ini dilakukan penulisan lebih berorientasi pada penelitian tarapan dan pendekatan yang digunakan adalah pendekatan survey. Untuk mengumpulkan data, telah ditentukan para informan yang akan memberikan informasi mengenai masalah yang diteliti. untuk mendukung penelitian ini diperlukan beberapa data, karena itu, dalam melaksanakan pengumpulan data digunakan metode Observasi atau pengamatan dan Wawancara. Hasil peneliitan Menjukan Peran Obudsman Republik Indonesia (ORI) Perwakilan Sulawesi selatan tersebut, dalam melakukan pengawasan Pelayanan Publik di Kota Makassar sesuai yang diharapkan yaitu melalui Seleksi laporan, Permintaaan klarifikasi, Investigasi, Wawancara dan Rekomendasi. Salah satu faktor penghambat Ombudsman Republik Indonesia (ORI) Perwakilan Sulawesi Selatan dalam melakukan pengawasan publik di Kota Makassar adalah Sumberdaya Manusia (SDM) dan Faktor pendukung Ombudsman Republik Indonesia (ORI) Perwakilan Sulawesi Selatan adalah Penggunaan teknologi informasi.
\end{abstract}

Kata Kunci : ORI Perwakilan Sulawesi Selatan, Pengawasan Pelayanan Publik 


\section{A. Latar Belakang Penelitian}

Undang-undang Republik Indonesia No. 25 tahun 2009 tentang Pelayanan Publik sudah di undangkan pada tanggal 18 Juli 2009, yang di maksud dengan pelayanan publik adalah kegiatan atau rangkaian kegiatan dalam rangka pemenuhan kebutuhan pelayanan masyarakat sesuai dengan peraturan perundang-undangan yang berlaku bagi setiap warga negara dan penduduk atas barang, jasa, dan atau pelayanan SDM yang disediakan oleh penyelenggara pelayanan publik. masyarakat mempunyai kewajiban sesuai dengan UU Pelayanan Publik, yaitu mengawasi dan memberitahukan kepada penyelenggaraan untuk memperbaiki pelayanan apabila pelayanan yang diberikan tidak sesuai dengan standar pelayanan yang berlaku; melaporkan penyimpangan pelaksanaan pelayanan kepada Ombudsman. Pengawasan penyelenggaraan pelayanan publik dilakukan oleh pengawas intern dan pengawas ekstern. Pengawasan intern penyelenggaraan pelayanan publik dilakukan melalui pengawasan oleh atasan langsung sesuai dengan peraturan perundang-undangan dan pengawasan oleh aparat pengawasan fungsional sesuai dengan peraturan perundang undangan. Sedangkan pengawasan ekstern penyelenggaraan pelayanan publik dilakukan melalui pengawasan oleh ombudsman dan pengawasan masyarakat.

Menurut Keputusan Presiden Nomor 44 Tahun 2000 tersebut, Komisi Ombudsman Nasional adalah lembaga pengawasan masyarakat berasaskan pancasila bersifat mandiri, serta berwenang melakukan klarifikasi, monitoring atau pemeriksaan atas laporan masyarakat mengenai penyelenggaraan negara khususnya pelaksanaan oleh aparatur pemerintahan termasuk lembaga peradilan terutama dalam memberikan pelayanan kepada masyarakat, dengan kata lain bahwa Komisi Ombudsman Nasional merupakan suatu lembaga negara yang bertujuan untuk memberikan perlindungan hukum terhadap hak-hak masyarakat yang diabaikan oleh aparatur pemerintahan khususnya dalam memberikan pelayanan publik tehadap masyarakat.

Salah satu tugas pokok Komisi Ombudsman Nasional tersebut adalah untuk mempersiapkan Rancangan Undang-Undang Ombudsman Nasional dan baru 8 tahun setelah ditetapkannya Keppres nomor 44 tahun 2000 itulah Undang-Undang Nomor 37 Tahun 2008 tentang Ombudsman Republik Indonesia disahkan dan mulai berlaku pada tanggal 7 Oktober 2008. Dengan ditetapkannya Undang-Undang Nomor 37 Tahun 2008 tentang Ombudsman Republik Indonesia maka diharapkan kinerja dan fungsi Ombudsman dapat lebih efektif dalam melakukan dan mengakomodir segala bentuk laporan-laporan maupun keluhan-keluhan masyarakat terhadap pelayanan publik yang dilakukan oleh aparatur pemerintahan. Adapun salah satu tujuan dari dibentuknya Ombudsman Republik 
Indonesia adalah untuk memberikan perlindungan hukum atas hak-hak warga negara dalam menerima pelayanan publik dari aparatur pemerintahan secara profesional serta untuk terbentuknya suatu pemerintahan yang baik, bersih, dan adil.

Belum Maksimalnya pelayanan publik dan masih banyaknya pungli Di Kota Makassar bukan perkara baru dan hal baru kita dengar. Hal ini sudah menjadi konsumsi publik. Tidak profesinalnya pelayanan yang dilakukakan instansi pemerintah Kota Makassar dalam melayani masyarakat merupakan hal buruk dan jauh dari pelayanan prima yang selama ini di idam-idamkan oleh masyarakat Makassar. Olehnya itu Ombusdman Republik Indonesi (ORI) Perwakilan Sulawesi Selatan harus bekerja keras untuk menghilangkan indikasiindikasi kecurangan dalam pelayanan publik ini, sehingga tidak ada lagi masyarakat yang dirugikan dalam hal pelayanan publik. Hal ini di akui pula oleh Subhan ST Ketua Ombudsman Republik Indonesia (ORI) Perwakilan Sulawesi Selatan bahwa pelayanan publik di Kota Makassar masih belum maksimal.Berdasarkan uraian fenomena latar belakang diatas, maka penulis merasa dan tertarik untuk melakukan penelitian Peran Ombudsman Republik Indonesia (ORI) Perwakilan Sulawesi Selatan Dalam Pengawasan Pelayanan Publik Di Kota Makassar.

\section{B. Rumusan Masalah Penelitian}

Adapun yang menjadi rumusan masalah dalam penelitian ini yaitu bagaimana mengetahui Peran Ombudsman Republik Indonesia (ORI) Perwakilan Sulawesi Selatan dalam Pengawasan Pelayanan Publik Di Kota Makassar dan Faktor-faktor apakah yang Mempengaruhi Kinerja Ombudsman (ORI) Perwakilan Sulawesi Selatan Dalam Mengawasi Kebijakan Publik Di Kota Makassar.

\section{Tujuan Penelitian}

Adapun tujuan dari penelitian ini yaitu untuk mengetahui Peran Ombudsman Republik Indonesia (ORI) Perwakilan Sulawesi Selatan dalam Pengawasan Pelayanan Publik Di Kota Makassar dan Untuk mengetahui Faktor-faktor yang Mempengaruhi Kinerja Ombudsman (ORI) Perwakilan Sulawesi Selatan Dalam Mengawasi Kebijakan Publik Di Kota Makassar.

\section{Kajian Pustaka}

\section{Konsep Pengawasan}

Pengawasan adalah salah satu fungsi organik manajemen, yang merupakan proses kegiatan pimpinan untuk memastikan dan menjamin bahwa tujuan dan sasaran serta tugas-tugas organisasi akan dan telah terlaksana dengan baik sesuai dengan rencana, kebijaksanaan, instruksi, dan ketentuan-ketentuan yang telah ditetapkan dan yang 
berlaku. Hakikat pengawasan adalah untuk mencegah sedini mungkin terjadinya penyimpangan pemborosan, penyelewengan, hambatan, kesalahan dan kegagalan dalam pencapaian tujuan dan sasaran serta pelaksanaan tugas-tugas organisasisetiap kekuasaan sekecil apapun cenderung untuk disalahgunakan. (Makmur : 2011).

Jenis-jenis pengawasan yakni pertama, Monitoring adalah kegiatan pemantauan atau pengamatan yang berlangsung selama kegiatan berjalan untuk memastikan dan mengendalikan keserasian pelaksanaan program dengan perencanaan yang telah ditetapkan atau Pemantauan (monitoring) adalah prosedur penilaian yang secara deskriptif dimaksudkan untuk mengidentifikasi dan/atau mengukur pengaruh dari kegiatan yang sedang berjalan tanpa mempertanyakan hubungan kausalitas.kedua Permintaan klarifikasi merupakan Ombudsman Republik Indonesia (ORI) adalah upaya yang dilakukan meminta klarifikasi (penjelasan) kepada pejabat publik sehubungan dengan adanya keluhan dari masyarakat.(Matsuri, 2005). Ketiga, Investigasi adalah Upaya penelitian, penyelidikan, pengusutan, pencarian, pemeriksaan dan pengumpulan data, informasi, dan temuan lainnya untuk mengetahui/membuktikan kebenaran atau bahkan kesalahan sebuah fakta yang kemudian menyajikan kesimpulan atas rangkaian temuan dan susunan kejadian. Keempat, Kata mediasi berasal dari bahasa Inggris Mediation yang artinya penyelesaian sengketa yang melibatkan pihak ketiga sebagai penengah atau penyelesaian sengketa secara menengahi. mediasi adalah intervensi terhadap suatu sengketa/negosiasi oleh pihak ketiga yang dapat diterima, tidak berpihak dan netral yang tidak mempunyai kewenangan untuk mengambil keputusan dalam membantu para pihak yang berselisih dalam upaya mencapai kesepakatan secara sukarela dalam penyelesaian permasalahan yang disengketakan. Menurut Muhibbin Syah (2010), Tanggapan adalah bayangan yang tinggal dalam ingatan kita setelah melalui proses pengamatan terlebih dahulu.Kelima, Dalam Kamus Besar Bahasa Indonesia (1994) Rekomendasi:rekomendasi artinya adalah saran yg menganjurkan (membenarkan, menguatkan) dan merekomendasi artinya memberikan rekomendasi; menasihatkan; menganjurkan, dan keenam Seleksi Laporan adalah upaya yang dilakukan Oleh Obudsman Republik Indonesia (ORI) sebagai tindak lanjut dari laporan masyarakat mengenai berbagai hal terkait penyelenggaraan pelayanan publik.

\section{Konsep Pelayanan Publik}

Pengertian pelayanan menurut Kitler dalam Sinambela (2006:4) adalah setiap kegiatan yang menguntungkan dalam suatu kumpulan atau kesatuan dan menawarkan keputusan meskipun hasilnya tidak terkait pada suatu produk secara fisik. Sedangkan menurut lukman dalam Sinambela (2006:5) bahwa pelayanan adalah suatu kegiatan atau urutan kegiatan yang terjadi dalam interaqksi langsung adalah seseorang dengan orang lain atau masih secara fisik dan menyediakan kepuasan pelanggan. Pendapat lain mengenai pelayanan menurut gronross dalam ratminto dan Winarsih (2006) pelayanan adalah suatu 
aktifitas atau serangkaian aktifitas yang besifat tidak kasat mata (tidak dapat diraba) yang terjadi sebagai akibat adanya interaksi antara konsumen dengan karyawan atau hal-hal lain yang disediakan oleh perusahaan pemberi pelayanan dimaksudkan untuk pemberi pelayanan yang dimaksudkan untuk memecahkan permasalahan konsumen/pelanggan. Pelayan berkaitan erat dengan masyarakat. Sehingga pelayanan lebih dikenal dengan istilah pelayanan publik. Publik berasal dari bahasa inggris public yang yang berarti masyarakat umum dan negara, kata publik dalam bahasa indonesia diartikan sebagai umum orang banyak dan ramai. Pelayanan publik menurut Sinambela (2006:5) adalah pemenuhan kebutuhan mayarakat oleh penyelenggara negara.

\section{Ombudsman Republik Indonesia (ORI).}

Sejak tanggal 07 Oktober 2008 Komisis Ombudsman Nasional (KON) telah berganti nama menjadi Ombudsman Republik Indonesia (ORI) seiring dengan disahkannya Undang-Undang Nomor 37 Tahun 2008 tentang Ombudsman Republik Indonesia oleh Presiden Republik Indonesia Susilo Bambang Yudhoyono. Menurut Pasal 2 Keputusan Presiden Nomor 44 Tahun 2000 tentang Komisi Ombudsman Nasional, yang dimaksud dengan ombudsman nasional adalah lembaga pengawasan masyarakat yang berasaskan Pancasila dan bersifat mandiri, serta berwenang melakukan klarifikasi, monitoring atau pemeriksaan atas laporan masyarakat mengenai penyelenggaraan negara khususnya pelaksanaan oleh aparatur pemerintahan termasuk lembaga peradilan terutama dalam memberikan pelayanan kepada masyarakat (Masthuri, 2005).

Menurut Undang-Undang No 37 tahun 2008 pada pasal 1 Ombudsman republik indonesia yang selanjutnya disebut ombudsman adalah lembaga negara yang mempunyai kewenagan mengawasi penyelenggeraan pelayanan publik yang diselenggarakan oleh penyelenggara negara dan pemerintah termasuk yang di selenggarakan oleh badan usaha milik negara serta badan usaha milik daerah, dan badan hukum milik negara serta badan swasta atau perseorangan yang diberi tugas menyelenggarakan pelayanan publik tertentu yang sebagian atau seluruh dananya bersumber dari anggaran pendapatan dan belanja negara dan / atau anggaran pendapatan dan belanja daerah.

Ombudsman tidak menyibukkan dirinya pada penegakan hukum yang sesungguhnya, akan tetapi tindakan-tindakan pemerintahan baik tindakan hukum maupun tindakan nyata atas norma-norma kepantasan. setiap orang mempunyai hak untuk meminta kepada ombudsman secara tertulis untuk memeriksa cara suatu organ administrasi telah bertindak dalam suatu keadaan tertentu terhadap seseorang atau suatu badan hukum. Ombudsman juga berwenang untuk/atas prakarsa sendiri mengadakan suatu pemeriksaan. Hasil pemeriksaan Ombudsman dibuat dalam bentuk laporan yang dikirimkan kepada organ bersangkutan yang berisikan hasil pemeriksaan dan pendapat atau rekomendasinya dan 
setiap tahun menyampaikan laporan kerjanya terhadap parlemen Belanda (staten general) yang walaupun laporan ombudsman tidak bersifat mengikat.

\section{E. Metode Penelitian}

Lokasi penelitian dilaksanakan di kantor Ombudsman Republik Indonesia (ORI) Perwakilan Sulawesi Selatan di Kota Makassar. Jenis penelitian ini dilakukan penulisan lebih berorientasi pada penelitian tarapan dan pendekatan yang digunakan adalah pendekatan survey. Untuk mengumpulkan data, telah ditentukan para informan yang akan memberikan informasi mengenai masalah yang diteliti. Penentuan informan dilakukan secara sengaja (purposive) beyaitu : Kepala Perwakilan ORI, Kepala Dinas Kependudukan dan Catatan Sipil, Kepala Kantor Imigrasi, Tokoh Masyarakat, dan Pengguna Layanan. untuk mendukung penelitian ini diperlukan beberapa data, karena itu, dalam melaksanakan pengumpulan data digunakan metode Observasi atau pengamatan dan Wawancara.

\section{F. Hasil Dan Pembahasan}

1. Peran Ombudsman Republik Indonesia (ORI) Perwakilan Sulawesi Selatan dalam Pengawasan Pelayanan Publik Di Kota Makassar

Peran Obudsman Republik Indonesia (ORI) Perwakilan Sulawesi selatan tersebut, dalam melakukan pengawasan Pelayanan Publik di Kota Makassar sesuai yang diharapkan. Berdasarkan data yang diperoleh di lapangan baik berupa studi pustaka, hasil observasi dan hasil wawancara terkait peran Obudsman Republik Indonesia (ORI) Perwakilan Sulawesi Selatan dalam pengawasan pelayanan Publik maka selanjutnya data tersebut di analisis sesuai klasifikasi data dengan pertanyaan penelitian dengan tujuan untuk memberikan deskripsi mengenai peran Obudsman Republik Indonesia (ORI) Perwakilan Sulawesi Selatan dalam pengawasan pelayanan Publik di Kota Makassar.

Data yang disajikan merupakan hasil analisis data baik berupa Studi Pustaka, hasil observasi dan hasil wawancara. Hasil analisis data berdasarkan klasifikasi data dengan pertanyaan penelitian kemudian di bahas dan dipaparkan guna menjawab pertanyaa penelitian. Adapaun hasil analisis data berdasarkan pertanyaan penelitian sebagaimana dijelaskan di bawah ini:

\section{a. Seleksi laporan}

Dalam menyeleksi laporan pengaduan masyarakat Ombudsman Republik Indonesia (ORI) perwakialan Sulawesi selatan disesuaikan dengan aturan -aturan yang ada dan disesuaikan dengan mekanisme perundang-undangan, pertama menerima laporan, kedua seleksi adminitrasi laporan dan meresume laporaran sehingga dengan semua itu bisa mengetahui bentuk laporan pengaduam masyarakat itu apakah sesuai dengan kewenngan 
ORI perwakialan Sulawesi selatan ini atau pun tidak sesuai dengan kewengan. Seluruh masyarakat sulawesi Selatan berhak menyampaikan laporan kepada OmbudsmanRepublik Indonesia (ORI) Perwakilan Sulawesi Selatan sepanjang mengenai tindakan pelayanan umum atau penyimpangan lain yang mengakibatkan buruknya kualitas pelayanan umum yang diterima masyarakat. Dalam hal ini masyarakat dapat menyampaikan laporan kepada Ombudsman Republik Indonesia (ORI) Perwakilan Sulawesi Selatan melalui beberapa cara, yaitu: Laporan Tertulis Langsung Biasanya masyarakat, Laporan Lisan Langsung Adakalanya Pelapor datang ke kantor Ombudsman tanpa sebelumnya menyiapkan laporan secara tertulis, Laporan Lisan Melalui Telpon. Tidak semua laporan masyarakat dapat ditindaklanjuti Ombudsman Republik Indonesia (ORI) Perwakilan Sulawesi Selatan. Secara umum ada tiga hal persyaratan yang harus terpenuhi. Persyaratan yang sifatnya administratif formal dan persyaratan yang menyangkut substansi terkait dengan kompetensi Ombudsman Republik Indonesia (ORI) Perwakilan Sulawesi Selatan, serta tidak melampaui masa kadaluarsa pelaporan. Penyusunan resume kasus dilakukan oleh Asisten Ombudsman Republik Indonesia (ORI) Perwakilan Sulawesi Selatan yang menangani laporan dan/atau menerima Pelapor pada saat menyampaikan laporannya secara lisan.

\section{b. Permintaaan klarifikasi}

Salah satu wewenang yang dijalankan Ombudsman Republik Indonesia (ORI) Perwakilan Sulawesi selatan adalah meminta klarifikasi (penjelasan) kepada pejabat publik sehubungan dengan adanya keluhan dari masyarakat. Untuk menindak lanjuti laporan yang sangat sederhana, Ombusman Republik Indonesia (ORI) Perwakilan Sulawesi selatan biasanya tidak perlu terjun kelapangan. Cukup melakukan telaah dokumen di belakang meja. Permintaan klarifikasi merupakan bagian terpenting dalam proses investigasi di belakang meja. Pada aspek ini Permintaan klarifikasi merupakan salah satu tindaklanjut yang dapat dilakukan oleh Ombudsman Republik Indonesia (ORI) perwakilan Sulawesi Selatan. Dalam kasus yang tidak terlalu rumit permintaan klarifikasi kepada Terlapor atau Atasan Terlapor dapat dilakukan berdasarkan investigasi di belakang meja. Oleh karena itu, dalam hal ini perlu dibedakan bentuk bentuk klari fikasi sebagai berikut: Klarifikasi di Lapangan (Klarifikasi Langsung) dan Klarifikasi Melalui Surat Resmi (Klarifikasi tidak langsung)

\section{c. Investigasi}

Investigasi merupakan salah satu kewenangan Ombudsman Republik Indonesia (ORI) Perwakilan Sulawesi Selatan dalam rangka menindaklanjuti kasus-kasus dugaan maladministrasi baik yang dilaporkan masyarakat maupun atas inisiatif sendiri (own motion investigation). Ombudsman Republik Indonesia (ORI) Perwakilan Sulawesi Selatan menganut dua tahapan sistem investigasi yang berjenjang. Tahap pertama adalah investigasi di belakang meja, yaitu memeriksa keputusan, surat menyurat atau dokumen- 
dokumen lain yang disampaikan Pelapor untuk memperoleh kebenaran laporan masyarakat. Apabila laporan yang disampaikan cukup kronologis dan objektif serta dokumen-dokumen pendukungnya cukup valid dan dapat dipertanggung jawabkan, Ombudsman Republik Indonesia (ORI) Perwakilan Sulawesi Selatan dapat saja langsung meminta klarifikasi guna memberikan kesempatan kepada pihak Terlapor untuk menjelaskan sebaliknya. Namun demikian, apabila laporan dan dokumen-dokumen yang disampaikan masih sangat awal dan minim, Ombudsman Republik Indonesia (ORI) Perwakilan Sulawesi Selatan masih harus meminta kelengkapan lebih lanjut dari Pelapor/Terlapor, dan untuk itu maka dapat segera dipersiapkan investigasi lapangan. Investigasi lapangan ini merupakan jenjang dan tahapan kedua setelah investigasi dokumen dilakukan di belakang meja. Pengertian lapangan bukan berarti semata-mata hanya di lokasi terbuka seperti misalnya tanah sebagai objek sengketa, tetapi meliputi juga ruangan kantor instansi dimana Terlapor bekerja. Investigasi lapangan dilakukan dengan meminta keterangan secara lisan dari Terlapor maupun Pelapor, ataupun pihak lain yang terkait langsung maupun tidak langsung dengan permasalahan yang dilaporkan.

\section{d. Wawancara}

Pada aspek ini wawancara merupakan alat yang sangat pokok dalam rangka mengumpulkan informasi sebanyak dan seakurat mungkin. Oleh karena itu, sebelum Tim Investigasi melakukan wawancara perlu diadakan persiapan mengenai sistematika dan metode yang tepat sehingga dengan demikian dapat dipastikan bahwa semua hal yang relevan dan perlu diketahui telah tercakup dalam kerangka wawancara yang akan dilakukan. Dengan sistematika dan metode yang tepat, wawancara akan menjadi alat yang efektif untuk mendorong terjadinya pengakuan yang benar/jujur dan sepenuhnya dari pihak yang diwawancarai. Dan tidak kalah penting adalah, setiap proses, tahapan dan hasil wawancara haruslah didokumentasikan secara baik, rapi dan seksama. Dokumentasi hasil wawancara akan sangat membantu Ombudsman Republik Indonesia (ORI) Perwakilan Sulawesi selatanmemperoleh gambaran yang lengkap tentang adanya dugaan tindakan maladministrasi yang dikeluhkan. Dalam hal ini setidaknya rekaman kaset merupakan keharusan dan bagian tidak terpisahkan dari dokumentasi. Berikut wawancara penulis dengan kepala Ombudsman Republik Indonesia (ORI) Perwakilan Sulawesi Selatan.

\section{f. Rekomendasi}

Rekomendasi Ombudsman Republik Indonesia (ORI) perwakilan Sulawesi Selatan dapat disusun sesuai kebutuhan penyelesaian permasalahan yang dilaporkan oleh masyarakat. Pilihan jenis rekomendasi yang tepat akan semakin memberikan efektifitas bagi tindak lanjut yang diambil Terlapor dalam merespon rekomendasi. jenis rekomendasi Ombudsman Republik Indonesia (ORI) perwakilan Sulawesi Selatan sebagai berikut : Pertama rekomendasi Membantu Penyelesaian Masalah Pelapor dimana rekomendasi jenis 
ini memang diformulasikan untuk membantu Pelapor agar masalahnya langsung tuntas. Misalnya, ada pelapor yang mengeluhkan lambannya pelayanan catatan sipil dalam menangani pengurusan akta kelahiran. setelah melakukan serangkaian investigasi dokumen dan/atau lapangan, Ombudsman Republik Indonesia (ORI) perwakilan Sulawesi Selatan menyusun rekomendasi untuk Pimpinan dinas catatan sipil yang dikeluhkan agar segera menindaklanjuti laporan tersebut dan memberikan pelayanan kepada yang bersangkutan disertai saran misalnya, Petugas catatan sipil yang dikeluhkan mesti ditindak, dan atau sistem pelayanannya mesti diperbaiki. Kedua,rekomendasi pemberian sanksi dimana rekomendasi ini adakalanya keluhan yang disampaikan masyarakat tidak secara langsung mengenai pelayanan umum. Tindakan beberapa oknum yang sewenang-wenang, koruptif dan sebagainya kadangkala menjadi salah satu penyebab buruknya kualitas pelayanan umum yang semestinya mereka berikan. Untuk keluhan seperti ini, Ombudsman Republik Indonesia (ORI) perwakilan Sulawesi Selatan dapat memilih susunan rekomendasi yang isinya memberikan pendapat dan saran kepada Atasan Terlapor agar Pejabat Publik yang dikeluhkan diperiksa, dan apabila terbukti bersalah diberikan sanksi sesuai ketentuan yang berlaku, atau diajukan ke Pengadilan Umum, Pengadilan Pidana atau Pengadilan Tata Usaha Negara. Jenis rekomendasi ini juga dapat dipadukan menjadi sekaligus untuk memberikan keuntungan langsung bagi Pelapor, misalkan agar permasalahan pokoknya (terkait dengan pelayanan) segera mendapatkan penyelesaian sebagaimana mestinya. Rekomendasi yang dapat dikirim oleh Ombudsman Republik Indonesia (ORI) perwakilan Sulawesi Selatan kepada Terlapor ialah agar Atasan Terlapor melakukan pemeriksaan, dan apabila terbukti telah melakukan tindakan maladministrasi agar dikenakan tindakan disiplin, sanksi administrasi sampai mengusulkan agar Terlapor diajukan di Pengadilan. Ketiga rekomendasi untuk mencegah tindakan maladministrasi dimana Rekomendasi ini, Ombudsman Rerublik Indonesia (ORI) perwakilan Sulawesi Selatan dapat diberikan kepada instansi Terlapor sebagai upaya pencegahan terjadinya tindakan maladministrasi. Ombudsman Rerublik Indonesia (ORI) perwakilan Sulawesi Selatan perlu memahami serta memiliki sensitifitas terhadap berbagai kemungkinan dan peluang terjadinya maladministrasi dalam kasus yang dilaporkan. Biasanya, maladministrasi antara lain dapat terjadi sebagai akibat adanya ketimpangan posisi sosial antara Pelapor dengan Lawannya. Lawan Pelapor yang memiliki kekuatan finansial lebih, kekuasaan serta pengaruh politik lebih, dan sebagainya sangat berpeluang menggunakan kelebihannya tersebut untuk mempengaruhi Pejabat Publik agar melakukan penyimpangan demi keuntungan pribadinya, dibandingkan dengan Pelapor yang hanya masyarakat biasa, tidak memiliki kemampuan finansial apalagi kekuasaan. 


\section{Faktor-Faktor yang Mempengaruhi Kinerja Ombudsman Republik Indonesia}

\section{Perwakilan Sulawesi Selatan Dalam Mengawasi Kebijakan Publik Di Kota Makassar}

Salah satu faktor penghambat Ombudsman Republik Indonesia (ORI) Perwakilan Sulawesi Selatan dalam melakukan pengawasan publik di Kota Makassar adalah Sumberdaya Manusia (SDM). Sumber Daya Manusia kini makin berperan besar bagi kesuksesan suatu organisasi dan merupakan juga asset utama suatu organisasi yang menjadi perencana dan pelaku aktif dari setiap aktivitas organisasi.Mereka mempunyai pikiran, perasaan, keinginan, status dan latar belakang pendidikan, usia, jenis kelamin yang hetorogen yang dibawa kedalam suatu organisasi.Sumber daya manusia yang cakap, mampu dan terampil belum menjamin produktifitas kerja yang baik, apabila moral kerja dan kedisiplinannya rendah. Mereka baru bermanfaat bila dapat mendukung terwujudnya organisasi. Sumber daya manusia yang ada di kantor Ombudsman Republik Indonesia (ORI) perwakilan Sulawesi Selatan masih belum terlalu memadai hal ini dapat dari jumlah pegawai Ombudsman Republik Indonesia (ORI) perwakilan Sulawesi Selatan. Padahal dalam melakukan pengawasan harus sumber daya manusia sangat diperlukan dalam melakukan auditdilapangan terkait kasus laporan pengaduan dari masyarakat untuk mendapatkan hasil yang maksimal.

Faktor pendukung Ombudsman Republik Indonesia (ORI) Perwakilan Sulawesi Selatan adalah Penggunaan teknologi informasi. Penggunaan teknologi informasi di Ombudsman Republik Indonesia (ORI) Perwakilan Sulawesi Selatan merupakan kebutuhan strategis. Saat ini Ombudsman Republik Indonesia (ORI) Perwakilan Sulawesi Selatan telah memiliki jaringan komputer dan infrastruktur yang cukup mendukung serta pengembangan jaringan terintegrasi yang bisa diakses dimana saja dalam memberikan pelayanan kepada masyarakat. Pengembangan jaringan terintegrasi yang dimaksud adalah penambahan fitur dalam modul pengaduan (case management system) yang terdapat dalam website Ombudsman Republik Indonesia (ORI) Perwakilan Sulawesi Selatan.

\section{G. Kesimpulan dan Saran}

\section{Kesimpulan}

Peran Ombudsman Republik Indonesia (ORI) sebagai institusi pengawas sekaligus merupakan wadah untuk menjembatani antara rakyat sebagai sumber kekuasaan dengan Pemerintah sebagai pemegang mandat kekuasaan tersebut Ombudsman Indonesia melakukan pertama seleksi Laporan Pada aspek ini Obudsman Republik Indonesia (ORI) Perwakilan Sulawesi Selatan melakukan seleksi laporan hasil pengadauan masyarakat. Dalam melakukan selekesi laporan Ombdsman Ri melakukan beberapa tahapan yaitu: Pada 
aspek ini Obudsman Republik Indonesia (ORI) Perwakilan Sulawesi Selatan melakukan seleksi laporan hasil pengadauan masyarakat. Dalam melakukan selekesi laporan Ombdsman Ri melakukan beberapa tahapan yaitu: Cara menerima laporan, Meneliti Persyaratan Administrasi Laporan dan Menyusun Resume Laporan, kedua, Pada aspek ini Permintaan klarifikasi merupakan salah satu tindaklanjut yang dapat dilakukan oleh Ombudsman Republik Indonesia (ORI) perwakilan Sulawesi Selatan untuk meminta klarifikasi (penjelasan) kepada pejabat publik sehubungan dengan adanya keluhan dari masyarakat, ketiga melakukan investigasi pada aspek ini Investigasi merupakan salah satu kewenangan Ombudsman Republik Indonesia (ORI) dalam rangka menindaklanjuti kasuskasus dugaan maladministrasi baik yang dilaporkan masyarakat guna memperoleh informasi yang lebih lengkap, tajam, seimbang dan objektif yang akan dijadikan bahan untuk merumuskan tindakan seperti apa yang dapat dilakukan selanjutnya, apakah meminta klarifikasi terlebih dahulu atau sudah segera dapat memberikan rekomendasi tertentu, keempat wawancara, Pada aspek ini wawancara merupakan alat yang sangat pokok dalam rangka mengumpulkan informasi sebanyak dan seakurat mungkin terhadap kasus yang ditangani dan ke lima rekomendasi, pada aspek Membantu Penyelesaian Masalah Pelapor dimana rekomendasi ini Idiformulasikan untuk membantu Pelapor agar masalahnya langsung tuntas.

Ombudsman Republik Indonesia (ORI) perwakilan Sulawesi Selatan dalam perjalananannya sebagai pengawas pelayanan Publik tentu memilki tantangan serta kendala dalam menjalankan tugasnya dimana salah satu faktor penghambatnya adalah keterbatasan Sumber daya Manusia (SDM) dalam melakukan pengwasan pelayanan publik sedangkan faktor pendukungnya adalah Penggunaan teknologi informasi dan komunikasi yang tersedia seperti perangkat komputer dan perangkat jaringan internet.

\section{Saran}

Berdasarkan pada rumusan kesimpulan sebelumnya maka yang menjadi saran dalam penelitian sebagai berikut:

1. Ombudsman Republik Indonesia (ORI) perwakilan sulawesi selatan memaksimalkan dan mengupayakan dengan segala kemampuanya untuk mencegah maladmintrasi dalam pelayanan publik di sulaewsi selatan ini agar tidak ada lagi masyarakat yang dirugikan lagi dalam pelayana publik walaupun sumber daya manusia yang dimiliki Ombudsman Republik Indonesia (ORI) perwakilan sulawesi selatan sangat terbatas.

2. Melakukan sosialisai kepada masyarakat agar tugas dan fungsi Ombudsman Republik Indonesia (ORI) perwakilan sulawesi selatan dapat diketahui masyrakat luas karena sampai saat masih ada masyarakat yang tidak mengenal tugas dan fungsi Ombudsman Republik Indonesia (ORI) perwakilan sulawesi selatan. 


\section{DAFTAR PUSTAKA}

Komisi Ombudsman Nasional. Peranan Ombudsman Dalam Pemberantasan Dan Pencegahan Korupsi serta Pelaksanaan Pemerintahan yang Baik. Jakarta: Komisi Ombudsman Nasional.

Mahsyar, A. (2011). Masalah Pelayanan Publik di Indonesia dalam Perspektif Administrasi Publik. Otoritas: Jurnal IImu Pemerintahan, 1(2).

Makmur. 2011. Efektivitas Kebijakan Kelembagaan Pengawasan, Bandung: RefikaAditama.

Masthuri, Budhi. 2005. Mengenal Ombudsman Indonesia. Jakarta: PT Pradnya Paramita.

Muhammadiah, M. (2011). Reformasi Pelayanan Publik Sebagai Strategi Mewujudkan Good Governance. Otoritas: Jurnal IImu Pemerintahan, 1(2).

Muhibbin, syah. 2010. Psikologi Pendidikan. Bandung : PT. Remaja Rosdakarya.

Sinambela, Lijan. (2012). Kinerja Pegawai: Teori, Pengukuran dan Implikasi. Yogyakarta: Graha IImu.

Tim Penyususn Kamus Pembinaan dan Pengembangan Bahasa. 1994. Kamus Besar Bahasa Indonesia, sedisi 2 cetakanke 3. Jakarta :BalaiPustaka.

Usman, J. (2011). Manajemen Birokrasi Profesional dalam Meningkatkan Pelayanan Publik. Otoritas: Jurnal Ilmu Pemerintahan, 1(2).

\section{Dokumen :}

Indonesia, Undang-Undang tentang Penyelenggara Negara yang Bersih dan Bebas Dari Korupsi, Kolusi dan Nepotisme. UU. No. 28 Tahun 1999. LN No. 75 Tahun 1999.

Indonesia, undang-Undang tentang Ombudsman Republik Indonesia. UU. No. 37 Tahun 2008.

Indonesia, Undang-Undang tentang Pelayanan Publik. UU. No. 25 Tahun 2009. LN No. 112 Tahun 2009. TLN No. 5038. 